\title{
The Impact and Aftermath of Coronavirus on Southern African Development Community Consumers
}

\author{
Josephine Shailemo \\ Department of Management, Texila American University, Namibia
}

\begin{abstract}
This paper is all about the impact and aftermath of corona virus (COVID-19) on Southern African Development Community (SADC) consumers. Major impacts as well as aftermath of COVID-19 were criticized and analyzed thoroughly to give more clarity. The study employed both qualitative and quantitative research designs, and the study was a descriptive research of a survey kind of. The targeted population was SADC consumers. The sample size of 200 consumers was taken from Namibia and South Africa only among other SADC countries. Questionnaires were drafted distributed and handed to respondents. Primary data was collected by the means of interviews as well as structured questionnaires, while Secondary data was collected from journals and by the use of internet. Data were analyzed and finally presented in a form of tables and pie charts. The two hypotheses (Null and Alternative) testing were identified, which led to the explanation of the phenomena. The study concluded that coronavirus is still affecting SADC consumers but anyway it is a worldwide pandemic and therefore no one knows when it will end. It was difficult for one to determine the exact outcomes of the aftermath of corona virus as it was still skyrocketing.
\end{abstract}

Keywords: Aftermath, Coronavirus, Consumers, Impact.

\section{Introduction}

No other virus has made headline globally compared to coronavirus [1] where Southern African Development Community (SADC) is no exception. Early December 2019, the world was hit by a deadly virus called corona virus. This deadly virus is dangerous and epidemic. It started in Wuhan-Hubei province in China.

It is believed that this novel virus is coming from eating or consuming bats and snakes. Other people are saying the virus is caused by technology $(5 \mathrm{G})$, as it was first rolled out in Wuhan city. Factories are coming to a standstill as many employees are affected, and those who are not affected are fearing for their lives.

The corona virus [1] has resulted in mass production shutdowns and supply chain disruptions due to port closures in China, causing global ripple effects across all economic sectors in rare "twin supply demand shock". Most of SADC countries also reported cases of COVID-19 and plans to control the further spreading of the deadly virus. With the help of World Health Organization [3] proper precautions are followed by countries worldwide. Global gross domestic product (GDP) growth is dropping negatively. Although Chinese growth will fall the in short term, it is expected to rebound quickly, some suggested this could even happen in the second quarter of 2020 when the virus will hopefully be contained. In the meantime, central banks are implementing measures to mitigate the effects of the virus on the economy, cutting interest rates and injecting liquidity into the banking system in some countries [2].

For the Southern African Development Community with the main objectives to achieve economic development, peace, security, growth and alleviate poverty, enhance the standard and quality of life of the people of Southern Africa, and support the socially disadvantaged through regional integration. Consumers are finding it hard to survive as they mainly depend on Chinese products, which is currently on lockdown no shipment of products are coming in. Markets are dropping drastically; some are even closing down as they have no products or stocks to sell to end-users.

\section{Statement of Research Problem}

Attention has thus far been directed to SADC consumers who mostly depend on the 
Chinese markets to start producing the same products as those that the Chinese market can offer. The time is now, corona virus is teaching marketers a lesson to be self- sustainable and independent for example now, marketers are inneedy of face masks but no SADC country manufacture masks, this simplifies that Chinese markets should tap in to assist.

This research purpose is to create awareness so that consumers are proactive and understand the danger of COVID-19 and with all its hindrances and obstacles it causes. On the other hand, the study is not only creating awareness but wants to establish whether there is a complete cure for corona virus. Furthermore, the study wants to know how consumers will survive the deadly virus, what to consume and what not. Finally, the study also wants to understand if SADC consumers can stand on their own and produce most of their local products without depending on the Chinese markets.

\section{Research Objectives}

The following objectives guided the study:

- To know how SADC Consumers will survive during the time of coronavirus.

- To determine challenges facing SADC companies and their marketers.

- To link the co-operation of SADC marketers and consumers with one another.

\section{Research Questions}

1. Is there a link of co-operation between SADC marketers and consumers?

2. How will SADC consumers survive during the time of coronavirus?
3. What are the challenges facing SADC companies and their marketers?

4. Is there a link of co-operation between SADC marketers and consumers?

\section{Research Hypotheses}

The following assumptions concerning the impact and aftermath of COVID-19 on SADC consumers were looked on:

\section{H1}

H1 a: SADC consumers know how to survive during the time of coronavirus.

$\mathrm{H} 1 \mathrm{~b}$ : There are challenges facing SADC companies and their marketers.

$\mathrm{H} 1 \mathrm{c}$ : There is a link of co-operation between SADC marketers and consumers.

\section{H0}

H0 a: SADC consumers do not know how to survive during the time of coronavirus.

$\mathrm{HO}$ b: There are no challenges facing SADC companies and their marketers.

$\mathrm{H} 0 \mathrm{c}$ : There is no link of co-operation between SADC marketers and consumers.

\section{Review of Literature}

\section{Introduction}

This is a chapter that yields the reader's insight with too much information and knowledge, and such a process can be very challenging as one has to combine viewpoints of various authors in order to arrive at a new viewpoint. Literature review includes a review of books, journals, internet as well as other publications to derive to a theoretical background of the study. 


\section{Conceptual Framework}

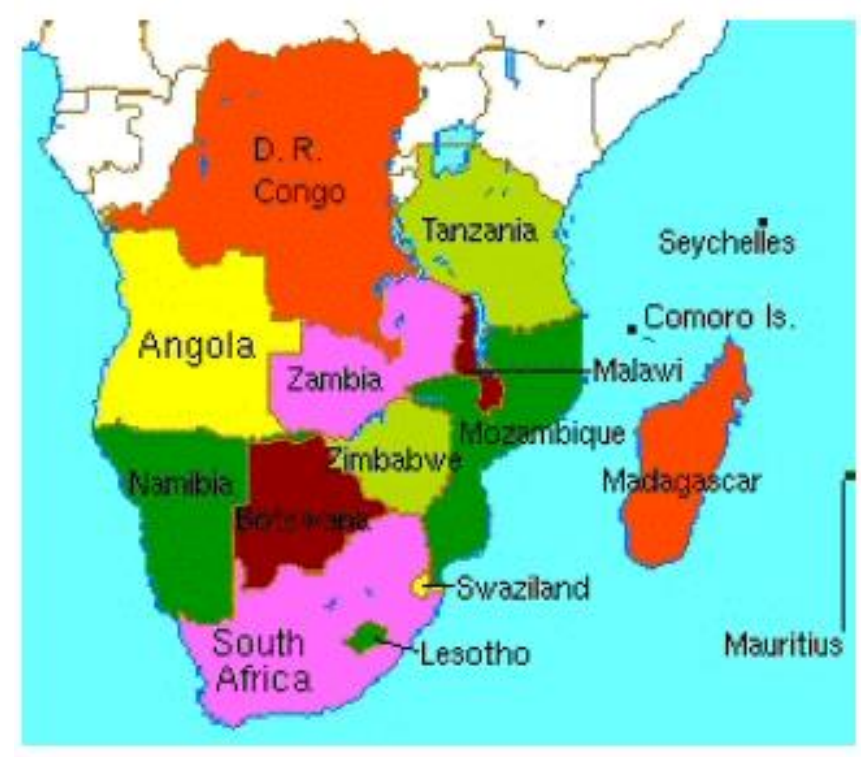

Figure 1. SADC Countries

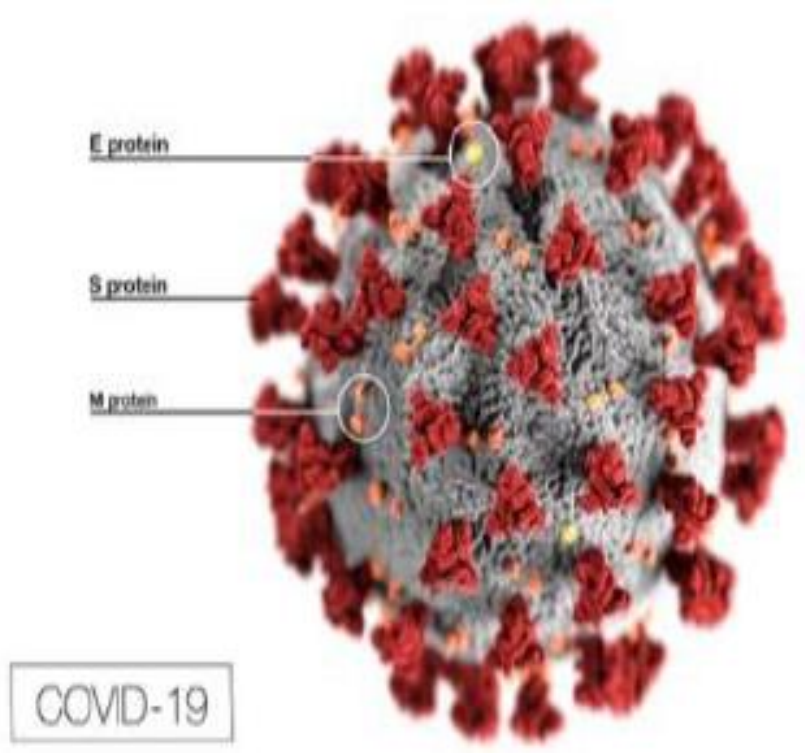

Figure 1a. COVID-19

\section{Theoretical Framework}

\section{Lockdown on SADC Countries}

Most of SADC countries are on lockdown due to corona virus [1] and this place a danger on the economy of countries. Business is on recess with no income, some are forced by the situation to close down or retrench valuable employees. A good example is that of a luxurious five-star Hilton hotel in the vicinity of Windhoek-Namibia, which forced its employees on unpaid leave for two consecutive months [4]. Another example is that of airline industry West Air, which retrenches some of its employees. West Air customers can be assured that the company has gone above and beyond the recommendations from the Word Health Organization [3] and all other local government and civil aviation agencies. The Covid-19 epidemic has resulted in travel bans across the globe as well as locally, with a negative impact on all aspects of the global economy, but an instant and devastating effect on travel and tourism [4].

There is a problem of cross border trade only essential services is allowed to operate, trucks that are transporting other various goods are stopped and only those that offer essential 
goods such as food, fuel and perhaps medicine. This places a burden on marketers who want to market their products to consumers, and in return consumers are suffering silently. There is a shortage of basic necessities to protect people from COVID-19 such as masks, gloves, sanitizers and other products relating to the prevention of COVID-19.

SADC countries are experiencing the problem of panic buying and overstocking of products whereby shops are left empty and are in the process of restocking, which is quite difficult for countries on lockdown could not ship or export goods or products to other countries. The lockdown on SADC countries places a control on countries to combat and contain the further spreading of COVID-19 to other places as people are restricted to stay where they are and strictly not to move around.

\section{The Impact of Corona Virus (COVID- 19) ON SADC Countries}

The 2019/2020 corona virus pandemic was confirmed to have spread to Africa on 14 February 2020. Experts have worried about COVID-19 spreading to Africa because many of the healthcare systems on the continent are inadequate, having problems such as lack of equipment, lack of funding, insufficient training of healthcare workers and insufficient data transmission. It was feared that the pandemic could be difficult to keep under control in Africa, specifically in SADC countries, and could cause huge economic problems if it spread widely. Matshidiso Moeti of the World Health Organization said that hand washing and physical distancing could be challenging in some places in Africa. Lockdown may not be possible, and challenges may be exacerbated by the prevalence of diseases such as malaria, HIV, tuberculosis and cholera. He further said that "a problem shared is a problem halved, SADC countries need to share the capacities available to them as much as possible nationally and regionally. The World Health Organization helped many SADC countries to set up laboratories for COVID-19 testing. Many preventative measures have been implemented in SADC countries, including travel restrictions, flight cancellations, event cancellations, school closures, and border closures [5].
Dar es Salaam/ Brazzaville, 10 March 2020ministers of health from the Southern African Development Community (SADC) agreed to harmonize and coordinate their efforts to respond to COVID-19 in the region. Since COVID-19 declared to be a public health emergency of international concern in February (2020); country preparedness levels in the WHO African region have been self- assessed to increase the rigor and reliability of the selfassessment processes, SADC Health Minister agreed to submit their survey results to peer review. These survey results shape members' state response planning and the assistance they receive from the World Health Organization [3].

Levels of preparedness vary considerably between SADC countries, and WHO is working with member states to address gaps in prevention, impact mitigation, and other intervention with emergency and contingency funds. Ten of the sixteen SADC member states also agreed to share information on the COVID-19 outbreak. These countries have reestablished and expanded the terms of reference for the technical committee responsible for coordinating and monitoring the implementation of the SADC Protocol on Health, comprising directors of public health and directors of medical services, said Ummy Mwalimu, Health Minister of Tanzania, and a lot of SADC ministers agreed to suspend regional face-to-face meetings in favor of internet-based conferences. While high-level coordination is vital to effectively respond to COVID-19, simply day-to-day measures are essential too. These include regular hand washing with soap and water, coughing or sneezing into a tissue or a bent elbow, being sure to safely dispose of the tissue afterward, maintaining a social distance of at least one meter, particularly if that person if coughing; avoiding touching the eyes, nose and mouth, and seeking medical attention early if a person develops a fever or cough.

The effects of COVID-19 spreading will have wider implications, not just on how economies function but also how consumers behave across the world [6]. COVID-19 induced changes in behavior could well prove a new tide-change in the direction of SADC's influence. The need for millions to retreat into self-quarantine, caused by the outbreak, has 
forced changes in the way many people have behaved for over a month now. Being cooped up at home for such an extended period will leave an indelible (if subtle) shift in how consumers in SADC countries behave in the future.

\section{The Aftermath of COVID-19 on SADC Consumers}

SADC countries are on lockdown, and the pace of life slows on the SADC consumers working from home is now a new thing. Consumers are now shopping online but this takes time for goods to be delivered or products mighty are the wrong one and some are lost in transit. SADC marketers are left in the dark there is nothing to market, no income, businesses are closing down, bartering and international trade are becoming impossible and deemed as things of the past.

Many SADC Consumers are not aware that life after lockdown on COVID-19 will be very different and must start preparing for a change of life-style right now. Those who are shorted think everything will be normal after lockdown but the opposite is true.

As we speak our future is uncertain for the next 12 months or so, people in urban areas will lose jobs and will struggle to pay rents, school fees, buy food and other necessities.

No one is certain that the end of lockdown would be the end of COVID-19, it might be the starting of armed struggle against the virus of which for now there is no end in sight. Every affected business will in turn affect those who also depend on it, including its workers and their dependents and other business too said Inga Matsuii, Zimbambwe [7]. S/he further added that the following will be affected severely:

\section{Cross Border Business}

Most of our cross borders were travelling to South Africa, Botswana, Tanzania, Dubai, China etc. and chances of these countries reopening their borders to the travelling public anytime soon are very slim. This business will close down at least for now until corona virus it termed.

Many countries will remain on lockdown for longer periods than currently anticipated. United Kingdom (UK) has already hinted that they will remain on lockdown for a year. China has also announced that it will guard its borders jealously to avoid reinfection from foreigners as they consolidate their victory over COVID-19. Here closer home, South Africa and Botswana are likely to do the same to avoid importing new cases. Besides the hospitality of these countries to cross borders, especially from Zimbabwe has all along been found wanting. This time they have a valid and genuine reason of banning cross borders, even for years.

In Zimbabwe, the Gulf, Mupedzanhamo and many other flea markets and boutiques country wide will be hard hit and all those surviving on that business will be rendered useless. While Francistown and Mussina risk becoming ghost towns without Zimbabwean cross borders, these two towns are economically stable and can manage.

\section{Tourism Business}

Hotels and lodges will open, but there will be no meaningful business. No international tourists are expected in the foreseeable future, meaning the sector will remain closed indefinitely. Automatically many workers in this sector will lose their jobs, especially in resort towns like Victoria Falls. The future of Victoria Falls remains oblique, the resort town faces the possibility of degenerating into a ghost town for a while.

\section{Other Companies}

While other companies will open for business after lockdown, not everyone will be recalled. Critical manpower will be called first, while other will be recalled at a later stage. Companies may need more time to recover, and some employees risk not being recalled at all.

\section{Gatherings}

Gatherings, of any kind and purpose, have been banned worldwide and no country will allow gatherings anytime soon as these have been singled out as responsible for promoting the spread of corona virus.

\section{Educational Gatherings}

The real challenge will be in education, especially in Africa. Schools are closed worldwide and while developed nations can resort to E-learning to avoid student gatherings, at least for a semester or two or even a year, Africa Zimbabwe has no such capacity. 


\section{Street Vending}

This will affect thousands of people mainly in big towns like Harare, Byo and Gweru. Many people who survive on street vending must quickly relocate to farms and rural areas, as they will not be able to pay rentals and buy food.

\section{Empirical Literature}

Studies from scientists at Princeton University undergoing peer review show that COVID-19 can survive in the air for up to three hours and can be transmitted in the air and can survive on inanimate surfaces for up to three days. "Tests Indicate Coronavirus Can survive in the Air" The Hill, March 11, 2020 accessible at [8].

People of all ages can be infected by the new coronavirus (2019-nCoV). Older people with pre-existing medical conditions (such as asthma, diabetes, heart disease) appear to be more vulnerable to becoming severely ill with the virus.

WHO advice people of all ages to take steps to protect themselves from the virus for example by following good hand hygiene and good respiratory hygiene. The most effective way to protect yourself against the new coronavirus is by frequently cleaning your hands with alcohol-based hand rub or washing them with soap and water.

Up to now there is no complete cure for coronavirus, Didier Raoult has just tested the coronavirus vaccine made in France and America in animals, but these animals are dead. Didier Raoult declares: it is a with great desolation that I have just done the test of vaccine again the coronavirus in animals but the latter are dead because this vaccine contains poison. Therefore, I have just understood that this vaccine is succinct and was created with the idea of exterminating human population (https://www.instagram.com/p/BW7ld5BflQ/?gshid=t9lk68cltpm7).

\section{Research Methodology}

\section{Research Design}

Research methodology as a systematic way of studying how research is to be carried out to solve a problem by describing, explaining and predicting phenomena, and there are many types of methodologies that can be used [9].
Although many researchers conducted studies on the impact of COVID-19 world - wide, the researcher conducted the same study but on SADC countries. This is a pure unsaturated study but similar study was conducted in China and Asia-Pacific which yielded the same results. The use of qualitative and quantitative approaches was employed for this study.

\section{Qualitative Research}

Qualitative research is a review approach in which the reviewer explores a central phenomenon and asks broad and general questions from participants on their views. These data are expressed in the form of words rather than numbers, but generally the researcher must search and explore with a variety of methods until a deep understanding is reached [10]. A qualitative study design is defined by Creswell [10] as "an inquiry process of understanding a social or human problem based on building or complex, or holistic picture, formed with words, reporting detailed views of respondents or informants, and conducted in a natural setting". Qualitative (flexible) research explores attitudes, behavior, and experiences through such methods as interviews or focus groups. It attempts to get an in-depth opinion from participants. As it is attitudes, behavior and experiences which are important, fewer people take part in the research, but the contact with these people tends to last a lot longer.

\section{Quantitative Research}

This research design emphasizes objectively in measuring and describing phenomena [11]. A research design which maximizes objectively by using numbers, statistics, structure and control.

\section{Descriptive Research}

Descriptive research is research in which a specific situation is studied either to see if it gives rise to any general theories, or to see if the existing general theories are borne out by the specific situation [12].

\section{Target Population}

A population is defined by [13] as the sum total of all the cases that meet our definition of the unit of analysis [14], refers to a population as the entirety of all the members, subjects or 
objects that conform to a set of criteria. The population is the whole group of individuals the researcher is concerned about to gain knowledge. The target population was SADC (which comprising 16 member states) consumers, but only two (2) member states [15] were selected for the study to be interviewed. Population of Namibia $=2.5$ million and South
Africa $=58.8$ million, all together equaling to 61.3 million.

\section{Sample Size}

A sample of 200 consumers [15] was interviewed for the study. The sample size will be $n=200$. The number of randomly selected participants are significant enough as to be related to a population of $\mathrm{N}=61.3$ million.

Table 1. Sample Size

\begin{tabular}{|l|l|}
\hline Countries & Consumers (selected for the study) \\
\hline Namibia & 100 \\
\hline South Africa & 100 \\
\hline Total & 200 \\
\hline
\end{tabular}

Source: Developed for this study

The number of randomly selected participants is significant enough as to be very relevant to a population of $\mathrm{N}=61.3$ million consumers. The researcher approached few consumers from the relevant population and selected elements to access easily until the sample reached the desired size of 200.

\section{Sampling Techniques (Procedures)}

The researcher uses a probability sampling procedure in which all elements of the selected population have an equal chance of participating using simple random sampling as a sampling method. A simple random sample involves drawing a sample frame of all units of population of interest and randomly selecting participants [16]. The participants referred to as respondents together represent a subset of the population that will be studied, their responses being analyzed, and the results inferred to the population.

\section{Research Instruments}

Research instruments are types of tools used in collecting data [17]. Research instruments are measurement tools (for example, questionnaires or scales) designed to obtain data on a topic of interest from research subjects. The research instruments that were employed to collect data in this study were questionnaire. The questionnaire was designed to collect both quantitative and qualitative data. Questionnaires with structures, semi-structured and open-ended, were employed. The researcher felt that questionnaires are more efficient, as they require less time and are less expensive and generate the collection of data from a larger sample.

(https://lib.dmu.edu/db/cinahl/insreuments).

\section{Data Collection Procedure}

Questionnaire is the most widely used technique for obtaining information from subjects [11]. Structured and unstructured questionnaires were sent to respondents, as they contain an explanation of the intended study and were used to analyses the impact and aftermath of COVID-19 on SADC consumers. The researcher approached the SADC Secretariat and some SADC Consumers and then distributed the questionnaires.

\section{Data Analysis}

All collected data were analyzed and quantified. Data analysis is the breaking down of respondents' results in a way as to answer the questions raised by the study [18], while Data analysis follows general procedures for quantitative research including preparing and organizing data, reducing data into themes through a process of coding, and representing data into figures, tables and discussions [19]. The study employed both quantitative and qualitative methods to analyses the data taken from the questionnaire, while extracted data from the questionnaire to group and categorize responses. Open-ended questionnaire was coded for results and closed-ended were combined for similarity, negativity or positivity. Questionnaire was distributed electronically via e-mails and few were posted and hand delivered. Both qualitative and 
quantitative findings were analyzed in a form of written and presented in tables, graphs and pie charts respectively. It was a dilemma to the researcher to come up with proper methods that would produce exact data to measure things like behaviors, attitudes and feelings of respondents.

\section{Validity of the Study}

Validity refers to "the degree to which the instrument measures what it is supposed to be measuring" [20]. Information that is valid is those that the researcher perceives as matching the concepts to be reviewed. The researcher focused on content validity, which refers to the accuracy in which an instrument measures the factors under study. The degree of validity also depends on the relationship between the variables, impact and aftermath of COVID-19 on the SADC consumers. Validity can be borrowed to internal validity. The internal validity of a study is a judgment that is made concerning the confidence with plausible rival hypotheses can be ruled out as explanations of the results [11]. Research instruments were tested for content validity by handing the questionnaires to SADC consumers. The questionnaires included on questions that seek clarity on the impact and aftermath of COVID19 on SADC consumers. The validity of all outcomes concerning the impact of COVID-19 on SADC consumers is valid as it is true that, COVID-19 hit-harder and destroy the wellbeing of many SADC consumers. The researcher can confirm that all the information obtained was accurately collected and analyzed.

\section{Reliability of the Study}

Reliability is the degree to which investigating, testing, observation or any other measuring procedure that produces the same result on frequent trials. It is the steadiness or regularity of scores over time or across rates [21]. Reliability relates to the precision and accuracy of the instrument. If used on a group of respondents in a similar result [22]. Respondents were informed of the purpose of the questionnaires as well as the interview and why they have to tell the truth.

Reliability is mostly used in quantitative research as to test the reliability of the consistency of the results when a study is being conducted for a period of time and when an instrument is used in a similar study yield similar results. Another definition of reliability suggests that measures or data collection methods should uninfluenced by change in the context [23]. In qualitative research, a study is deemed reliable when the quality of information to be reviewed is likely to generate understanding. Likewise, irrelevant data that does not apply to the study is unreliable.

\section{Limitations of the Study}

The researcher faced a shortage of participants who provided honest information as requested. Not all consumers were able to understand the research purpose, and the language used. Time was one of the limitations, as it was not adequate for the researcher to carry out the study. Hence, the results might yield valid but unreliable conclusions.

The researcher aims to carry out research in all SADC countries but the current state (situation is not possible due to lockdown), time, transport and resources were very minimal, Hence, the study was only conducted in two SADC countries [15]. The behavior and reactions from respondents were another limitation in data collection process. The limitations of the study are those characteristics of design or methodology that impacted or influenced the interpretation of the findings from your research [24].

\section{Delimitations of the Study}

Delimitations are those characteristics that limit the scope and define the boundaries of the study [25]. The delimitations are in the researchers' control. Delimitation factors include the choice of objectives, the research questions, variables of interest, theoretical perspectives that are adopted (as opposed to what could have been adopted) and the population investigated. The delimitation section of the study explicates the criteria of participants to enroll in the study, the geographic region covered in the study, and the profession or organisation involved. The study targeted consumers in Southern African Development Community (SADC), but it focused only on consumers from Namibia and South Africa.

\section{Ethical Considerations (issues)}

Rahman [26] defines research ethics as a way to deciding how to act and analyses broad 
issues or problems during a study, while Pera \& van Tonder [27] defines ethics as a code of behavior considered correct. All respondents were treated with confidentiality and were not asked to reveal their credentials. Questionnaire designed are not biased, and all information furnished by respondents was kept confidential.

Welman, Kruger \& Mitchell [28] identified four main ethical considerations to which a researcher should adhere to:

- Informed consent-the researcher obtained the necessary permission from the respondents after thoroughly briefing and informing them of the purpose of the research.

- Right of privacy-respondents were informed about their right to privacy and their identity were not revealed.

- Protection from harm - the safety of respondents was guaranteed from physical and emotional harm.

It is very important that all researchers are aware of research ethics. Ethics relate to two groups of people; those conducting research, whom should be aware of their obligations and responsibilities, and the "researched upon" who have basic rights that should be protected [26]. Respondents were informed of the intention or the purpose of the research before completing the questionnaire and those who agreed were used in this study.

\section{Result and Discussion}

This chapter presents the demographic characteristics of the respondents and the research findings from the study. Data are analyzed systematically based on the objective of the study. Also, the chapter provided the gathered data and researcher's analysis and interpretation, in which all primary and secondary research conducted by the researcher and the results are presented into tables, bar charts and graphs as well as pie charts. Below each figure or table, the results are well depicted, described or discussed, interpreted, and some are linked to literature review where applicable. All of 200 questionnaires distributed were returned answered.

Questionnaire was divided into three sections, namely:

Section A: Demographic data.

Section B: Impact of COVID-19 on SADC consumers.

Section C: Aftermath of COVID-19 on SADC consumers.

Section A: Demographic data.

This section is about a collection of SADC consumers' demographic data; like gender/sex, age as well as their employment rate.

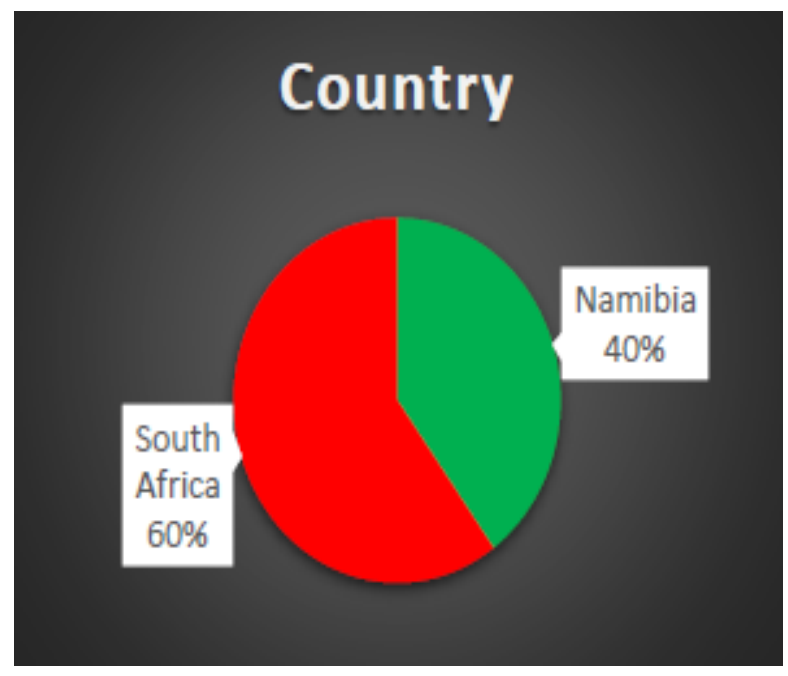

Figure 2. Shows Gender (Male) 


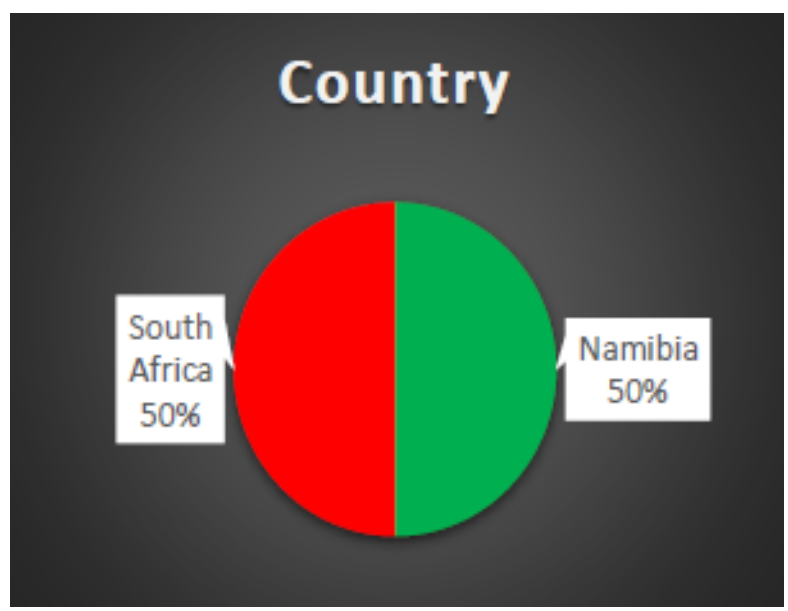

Figure 3. Shows Gender (Female)

The results in Figure 2 show that $60 \%$ of respondents are South African males, while the $40 \%$ of the respondents are Namibian males.
Figure 3 shows that both two countries (Namibia \& South Africa) have equal score/rate of $50 \%$ of female who responded.

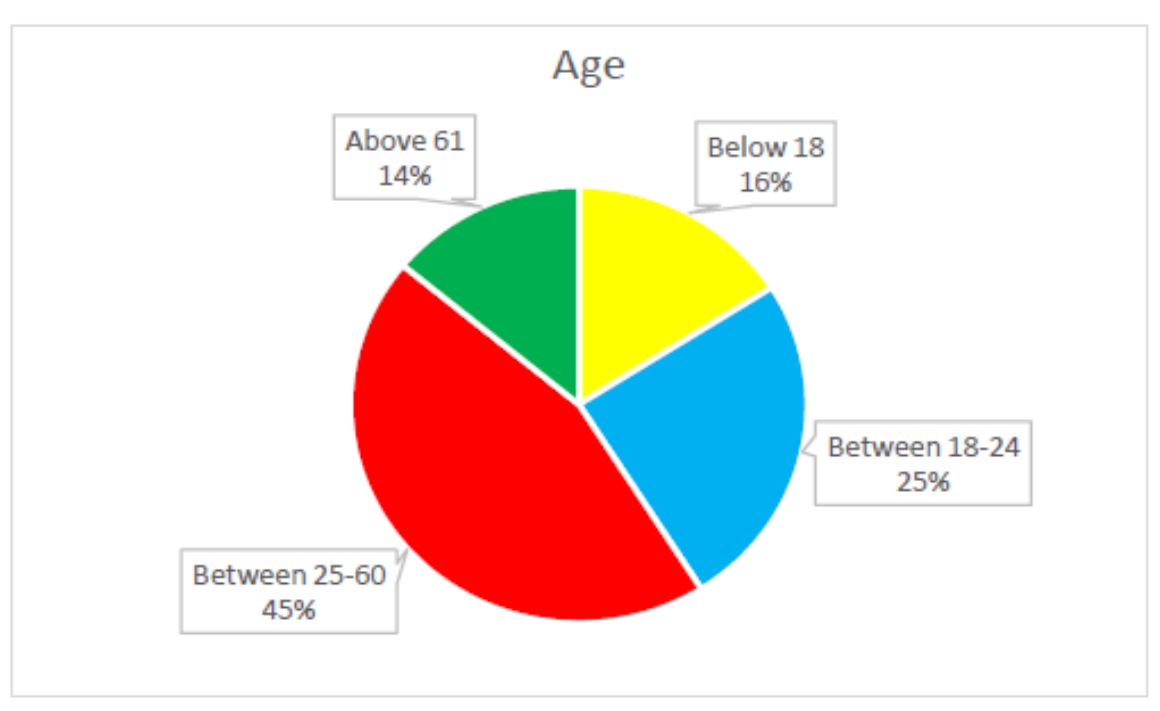

Figure 4. Age Range

Source: Research results (2020)

The study shows that respondents (consumers) between the ages of 25-60 are more than others. Their consumption rate is very high compared to others; this is the age range of working class they have to pay bills, so their responsibilities are far too much compared to other age range. The second age range is the one between the age of $18-24$, with $25 \%$, this age range consists of varsity students who are at tertiary institutions as well as those who did not make it in grade 12 (matric) who are struggling to make ends meet. Finally, $16 \%$ and $14 \%$ is made up of age range below 18 and those of 61 and older; these two-age ranges are often labelled and called the dependent age group because they can hardly strive for themselves but depend more on others.

Table 2. Respondents who are Employed

\begin{tabular}{|l|l|l|}
\hline & No. of Respondents & Accumulative Percentage \\
\hline Yes & 120 & $60 \%$ \\
\hline No & 80 & $40 \%$ \\
\hline Total & 200 & $100 \%$ \\
\hline
\end{tabular}

Source: developed for the study 
The table depicts the percentages of respondents (consumers) who are employed and those who are not employed. It shows that $60 \%$ are employed while $40 \%$ are not employed (out of 200 respondents/consumers 120 are employed and 80 are not employed).

Section B: Respondent's knowledge on the impact of COVID-19 on SADC consumers.

Table 3. Respondents (Consumers) Awareness on COVID-19

\begin{tabular}{|l|l|}
\hline Yes & 200 \\
\hline No & 0 \\
\hline
\end{tabular}

Source: developed for the study

The table (table 3 ) depicts the numbers of respondents who are aware of the impact of COVID-19 on SADC consumers. All respondents are very much aware of the coronavirus and how it spread.

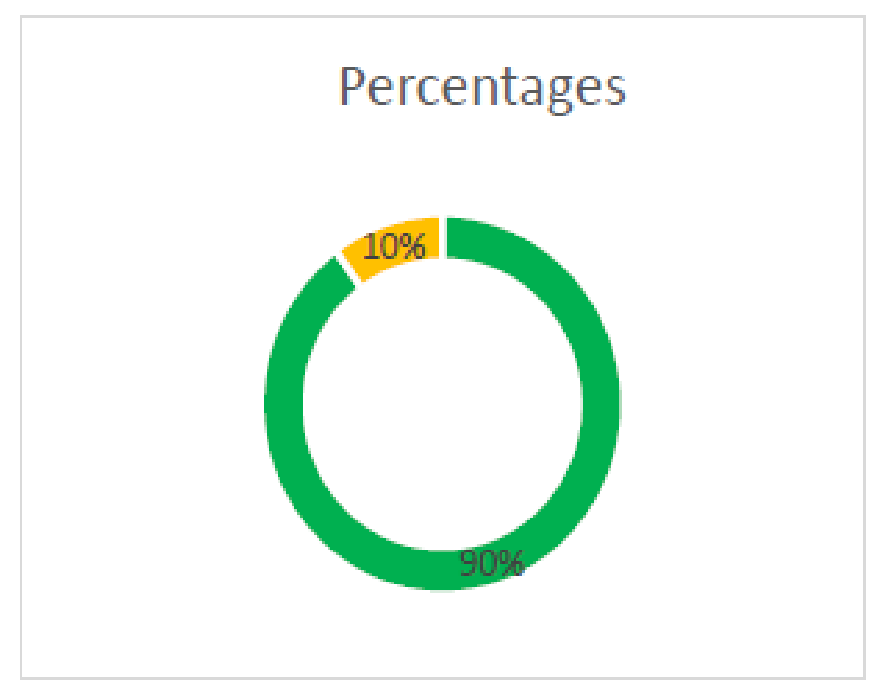

Figure 5. Government Alternative Measures

As indicated in the figure (Fig.5) $90 \%$ of respondents agreed that the government has come up with alternative measures to assist citizen to combat and contain COVID-19 only $10 \%$ of respondents who disagree that the government has not done anything to assist citizen.

Respondents who said that the government has come up with alternative measures to assist citizen, the followings are some measures that they have identified:

- Hygiene products to be used such as hand sanitizers, wearing of masks and gloves especially in public places.

- Creating awareness on COVID-19 through social media, television, radios and other means of communications.

- Closing of borders to all except for essential services.
- Instructing of central banks to lower repo rates so that commercial banks will follow suit.

- Introduction of emergency grant to nonworking citizens and those who lose their jobs.

All of these are kinds of measures that government come up with to assist citizens.

The following are some of the impacts of COVID-19 on SADC consumers

- Death rate has increased drastically, more demands of medicines and other medical supplies such as ventilators

- Shortage of consumable products.

- Closure of businesses.

- Production rate decreased.

- Consumption rate increased. 


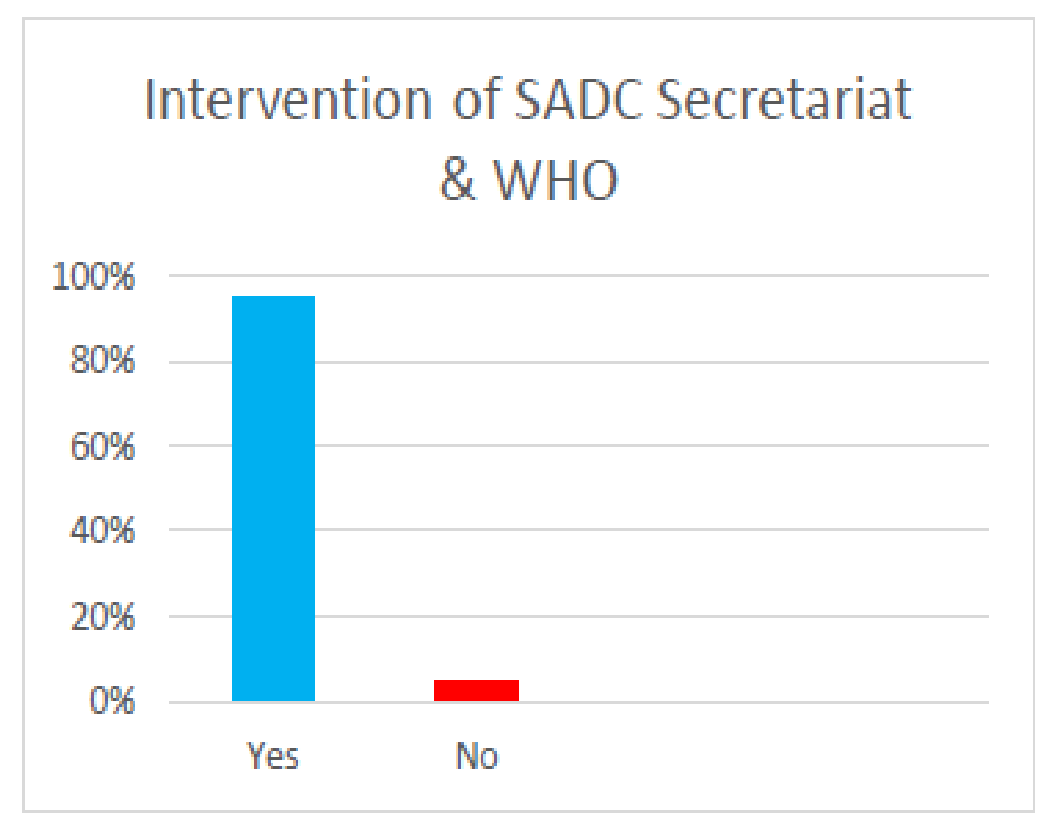

Figure 6. Intervention of SADC Secretariat \& WHO

Source: developed for the study

Figure 6 shows the majority of respondents agreed with $95 \%$ while fewer respondents did not agree with a score of $5 \%$. One can draw a line between the two (yes and no) that many have agreed.

Those who agreed to have this to say. SADC Secretariat really intervened; countries are sharing information and updating each other on what is happening. SADC countries are communicating on ways to assist each other, like recently Namibia opened the Oshikango border to allow Angolan who are seeking medical help to be assisted, while other borders are strictly only open for essential services.

Section C: Aftermath of COVID-19 on SADC consumers.

Respondents were asked to give their thought and opinion on what will happen after COVID-19. These are their thoughts.

- The livelihood of SADC consumers will change drastically, as things will be more expensive than before.

- More orphans as parents will perish due to COVID-19

- Billion children's education will be derailed by shutdowns.

- Changes in education system, the introduction of e-learning and lifelong learning.
- The pandemic will trigger massive losses for big companies and small businesses and will force millions of people out of work.

- The reduction of manpower overtaken by the work of machines (automation).

- The introduction of Artificial Intelligence (AI) which will be rolled out globally.

- Many of the SADC countries will incur more debts as they are forced by COVID19 to borrow and lend money and products from other countries, and this will take longer to pay back such loans.

\section{Summary}

The study is all about the impact and aftermath of COVID-19 on SADC consumers. The study analyses the impact and it further predict what will happen to SADC consumers in the future [1].

The research objectives which answer research questions identified were:

- To know how SADC consumers will survive during the time of coronavirus.

- To determine challenges facing SADC companies (marketers).

- To link the co-operation of SADC marketers and consumers.

\section{Research questions were}

1. How SADC consumers survive during the time of coronavirus? 
2. What are the challenges facing SADC companies/marketers?

3. Is there a link of co-operation between SADC marketers and consumers?

4. All the hypotheses (H1 \& H0) tested indicated that:

\section{H1- Alternative hypothesis}

H1a: SADC consumers know how to survive during the time of coronavirus.

H1b: There are challenges facing SADC companies/marketers.

H1c: There is a link of co-operation between SADC marketers and consumers.

\section{HO - Null hypothesis}

H0a: SADC consumers do not know how to survive during the time of coronavirus.

HOb: There are no challenges facing SADC companies/marketers.

H0c: There is no link of co-operation between SADC marketers and consumers.

The testing of the two hypotheses (null hypothesis \& alternative hypothesis) led to the explanation of the associated phenomena. The study found out that both two hypotheses are correct meaning there is a correlation between the two. The study identified some of the impacts of COVID-19 as well as (the aftermath) what will happen in the future after COVID-19 ends.

\section{Conclusion}

The study presented the existing literature covering impact and aftermath of COVID-19. Although what is being research is an ongoing process, nobody knows when the virus will stop or ends. Measures and precautions are being taken care of, it is a world- wide pandemic even if the study was conducted in SADC countries only lots of lives are lost, the damage is done let's hope for a better tomorrow.

\section{Suggestion for Future Research}

While many people are just passively reading papers and books, one should try to work it all out in some details, analyze and, if possible, research more about it so that you will understand to the core. This study is an ongoing process because it was conducted during the beginning of the pandemic of coronavirus. It is advisable to motivate the young researchers to take up challenging problems.

\section{Future research is recommended}

- When coronavirus ends to determine the severe damage, it has caused and how many people have perished.

- Researches in the entire world might be compared and conducted to give true reflections of what has really transpired, whereby different methods and populations are considered.

- The study suggested that more researches be carried out to determine the true cause of coronavirus.

- The impact of the coronavirus is not a one man's show a group of researchers is advisable to come together as one and conduct research.

- From the results and finding of the study, SADC consumers and marketers are urged to rely on their homegrown products and not depending much on overseas imported products.

- Similar studies may be conducted in areas not covered by this research.

Hopefully, this study might raise concerns and yield good points to SADC consumers and marketers at large in terms of issues concerning the society and also to other researchers that might need to build on this study and use it as a secondary data. 


\section{References}

[1] COVID-19 South African coronavirus news and information portal. SA Corona virus Portal. Retrieved 29 March 2020.

[2] https://www.bakermckenzie.com/en/insight/publi cations/2020/03/the-impact-of-covid19-on-keyafrican-sectors/

[3] https://www.afro.who.int/news/south-africandevelopment-community-unites-tackle-covid-19 Retrieved on 27 March 2020.

[4] New Era newspaper 25, March 2020.

[5] En.m.wikipedia.org/wiki

[6] https://www.mintel.com/blog/consumer-marketnews/research-your-way-out-of-a-crisis-covid-19seffect-on-consumer-behaviour.

[7] Matsuii, I. (2020). A Critical Analysis.

Education Vol 35 No. 2: 66-67; Structure: How to Structure the Research Limitations Section of your Dissertation. Dissertations and Theses: An online Textbook. Laerd.com.

[8] https://www.thehill.com/policy/healthcare/48711 0 -tests-indicate-coronavirus-can-survive-in-the-air.

[9] Rajasekar, S., Philominathan, P. \& Chinnathambi, V. (2013). Research Methodology. arXiv: Submit/0821442 [physics. ed-ph] 14 Oct 2013

[10]Creswell, J.W. \& Clark, V.L. P. (2014). Principles of qualitative research: Designing a qualitative study. Journal of Management, 7-9.

[11]McMillan, J. \& Schumacher, S. (2014). Research in Education: Evidence-Based Inquiry. England. Pearson Education Limited.

[12] Goddard, W. \& Melville, S. (2001). Research Methodology: An Introduction. (2 ${ }^{\text {nd }}$ Edition). Juta \& Co. Ltd.

[13]Mouton, J. (2006). Understanding Social research. Pretoria. South Africa.

[14] Welman, R., Kruger, K. J. and Mitchell. (2009). Research Methodology, Cape Town, South Africa: Oxford University's.

[15] Katjiheve, Charmaine (28 March 2020). Update: Namibia confirms 11 COVID-19 infections: The Namibian.

[16] Nambira, G. (2016). Research Methodology. Lecture.

[17]Cohen, L. (2010). Research Methods in Education.
[18] Weiwei, T. (2010). Impact of corporate image and corporate reputation on customer loyalty. Management Science and Engineering, 1 (2), 57-62. [19] Becker, W. S. \& Burke M. J. (2012). The staff Ride: An Approach to Qualitative Data Generation and Analysis.

[20]Polit, D. F. \& Hunger, B. P. (1995). Nursing Research, Principles and Methods, Philadelphia PA, JB Lippincott.

[21] Howell, J., Miller, P., Park, H., Sattler, D., Schack, T., Spery, E., Widhalm, S., \& Palmquist, M. (2012). Reliability and Validity.

[22] Cohen, L., Marion, L. \& Morrison, K. (2000). Research Methods in Education. London: Routledge/Falmer.

[23]Edwards, A. \& Talbot, R. (1994). A Research handbook for the caring professions. Longman Group Limited. New York.

[24]Price, J. H. \& Murnan, J. (2004). Research Limitations and the necessity of Reporting Them". American Journal of Health.

[25] Simon, M. K. (2011). Dissertation and Scholarly research: Recipes for Success. Seattle, WA, Dissertation Success, LLC.

[26]Rahman, M. S. (2010). Service quality, corporate image and customer satisfaction towards customer perception: An exploratory study on Telecom customers in Bangladesh. Business Intelligence Journal, 56-62.

[27]Pera, S. A \& Van Tonder, S. (1996). Ethics in Nursing Practice. Juta \& CO Ltd, Landsowne.

[28] Welman, K., \& Mitchell, A. (2005). Research Methodology. Cape Town: Oxford University Press. [29] Colorado State University. Retrieved from https://writing.colostate.edu/guides/guide.cfm?guide $\mathrm{id}=66$.

[30]Education Vol 35 No. 2: 66-67; Structure: How to Structure the Research Limitations Section of your Dissertation. Dissertations and Theses: An online Textbook. Laerd.com.

[31] Sekaran, U. (2003). Research Methods for Business, A Skill-Building Approach. $4^{\text {th }}$ ed. John Wiley \& Sons, New York. 